\title{
Study on Vegetation Concrete Technology for Slope Protection and Greening Engineering
}

\author{
Junfeng Cheng ${ }^{1,2}$, Xiaoyong Luo ${ }^{1,2 *}$, Zhiyong Shen ${ }^{1}$, Xuqiang Guo ${ }^{1}$ \\ ${ }^{1}$ School of Civil Engineering, Central South University, 68 South Shaoshan Rd., Changsha, Hunan, 410075, China \\ ${ }^{2}$ Prefabricated Construction Engineering and Technological Research Center of Hunan Province, \\ 68 South Shaoshan Rd., Changsha, Hunan, 410075, China
}

Received: 30 October 2019

Accepted: 9 April 2020

\begin{abstract}
In this work, to further investigate the vegetation concrete technology for slope protection, a total of 10 groups mix proportion specimens of porous concrete were designed and constructed. As a result, the impacts of different parameters include the fly ash and silica fume contents on the mechanical properties and porosity as well as the $\mathrm{pH}$ value of porous concrete were discussed. Meanwhile, ecomodified soil with resistance to the erosion of rainwater was sprayed on the surface of porous concrete for the survival of native grass growth. In addition, the growth characteristics of the Festuca arundinacea schreb (Chinese grass) within eco-modified soil on the surface of porous concrete were observed and monitored for 8 weeks including the average height, root system development and relative coverage of grass. The results show that the compressive strength and porosity of porous concrete measured after 28 days were at least $13 \mathrm{Mpa}$ and $21 \%$ respectively, indicating the porous concrete is suitable for the slope protection in practical engineering. Furthermore, the integration of eco-modified soil and porous concrete was successful, and all grass survived in the eco-modified soil and porous concrete environment for the duration of the observation period, and the coverage rate of vegetation reached $96 \%$ or above. It was also found that the roots system has permeated the pores of porous concrete and reached the bottom of porous concrete after 8 weeks.
\end{abstract}

Keywords: slope protection, porous concrete, eco-modified soil, mix proportion, silica fume

\section{Introduction}

The bare slopes widely prone to suffer from natural disasters such as soil erosion, water runoff, and landslides under the action of rainwater scouring, and it is also found that the natural environment easier to damage for slope protection construction

*e-mail: csu-luoxy@csu.edu.cn
[1]. Consequently, it needs to attach importance to eliminate these natural disasters in slope protection engineering. For this purpose, inorganic methods are usually performed to provide the structural stability for slope protection based on geotechnical investigations [2]. In the past few decades, those inorganic methods include hydro mulch geotextiles, wire mesh and soil stabilizer were adopted for the slope protection in practical engineering [3-4]. However, the initial cost of inorganic method is higher due to both application and production of slope protection system. Meanwhile, 
although these methods exhibit durable characteristics, and still need general maintenance costs as well as substantial costs associated with extensive restoration or total replacement [4-8]. Accordingly, some researchers have done some studies on the vegetation for slope protection as a novel approach to protect the slope from water runoff, and which is considered one of fast and environment friendly method to forbid soil erosion [9-12]. For this purpose, vegetation concrete combines vegetation with porous concrete, and it was widespread performed in slope protection. In this case, the mediums and nutrients include water, air, fertilizer and soil were provided by pass freely continuous pores to survival of roots system in porous concrete, and thus vegetation can germinate and roots penetrate through concrete frame into undisturbed soil strata. Therefore, it is necessary to pay attention to the vegetation concrete technology, which enhances the structural stability for slope protection and meanwhile also promotes plant growth.

It was worth mentioning that many scholars have done numerous investigations on the properties of porous concrete. $\mathrm{Hu}$ et al. [10] conducted the performance tests on the porous concrete, and found that the porosity was the main factor influencing the plant growth characteristics. Meanwhile, the porosity of $20 \% \sim 30 \%$ and the average diameter of pore in range of $2 \sim 3 \mathrm{~mm}$ was considered necessary for the growth of plants in porous concrete. In Ref. [11], single aggregate with a diameter of $10 \mathrm{~mm} \sim 20 \mathrm{~mm}$ was used to construct the porous concrete, and found that porous concrete with diameter greater than $10 \mathrm{~mm}$ exhibits better permeability and capacity of drainage. A single gradation aggregate between $20 \mathrm{~mm}$ and $40 \mathrm{~mm}$ can be casted into porous concrete with a porosity of nearly $40 \%$ [10]. In addition, the water-binder ratio in range of 0.25 to 0.4 is widely used in the mix design of porous concrete [12]. The compressive strength of 15.7 $\mathrm{MPa}$ and the aggregate diameter is range of 10 20 $\mathrm{mm}$ was designed and constructed for the porous concrete in [11]. The compressive strength of porous concrete above $20 \mathrm{MPa}$ by adding an admixture named SR-3 was proposed in literature [13]. As a result, the above results indicate that the strength, porosity and water-binder ratio were crucial indicators to cast the porous concrete.

Furthermore, some studies have turned to the field of ecological engineering combined with conventional slope protection method. Chen et al. [14] examined the influence of cement content on the germination and growth of seeds, and the principle of hydro mulching and the concrete shotcrete technology were combined. It was found that the matrix should contain $8 \%$ of cement content as stabilizer to provide the optimal vegetation growth condition, and which enhances the stability and protection for the gradient slope. Shi and Kong [15] proposed that vegetation concrete should be prefabricated to reduce construction or cast-insitu period significantly for effective slope protection.
Moreover, the growth environment of plants as one of the main factors to limit the development of vegetation concrete. It is generally known that the hydration reaction of Ordinary Portland Cement (OPC) causes the alkalinity or $\mathrm{pH}$ value in concrete up to 12-13. However, vegetation only survives in soil with a certain $\mathrm{pH}$ value in the range of 3.5 to 9.5 . Therefore, the porous concrete cast by OPC is not suitable for the growth of ground and aquatic plants when the concrete was not treated with alkali reduction. In this regard, Bao et al. [16] reduced the alkalinity of porous concrete by adding self-designed admixture to the cement paste. Meanwhile, it was found that the compressive strength of porous concrete exceeds $25 \mathrm{MPa}$ when the admixture mixed approximately $3.6 \%$ of cement (mass fraction), and the growth of vegetation also extremely flourishing.

A study by Gao et al. [11] presented that fly ash and silica fume were used to replace cement in porous concrete, and thus the alkalinity in concrete decreased significantly. It was indicated that the $\mathrm{pH}$ value declined to 9.8 after 28 days and 9.0 after 90 days respectively by adding $5 \%$ of silica fume into concrete. Meanwhile, the alkalinity in concrete reduced to 10.0 after 90 days curing when the additive of $40 \%$ fly ash was mixed in concrete. Nevertheless, the planting and growth of vegetation have not been conducted for this type of porous concrete, and the growth of grass needs further discussion. Accordingly, it is feasible to plant alkali-resistant grass in the porous concrete treated by alkali reduction. $\mathrm{Xu}$ et al. [17] conducted experimental studies to examine the growth of grass in porous concrete, in the test, the soil and nutrients were filled into the pores of hardened concrete immersed in $\mathrm{FeSO}_{4}$ solution. It was observed that the festuca arundinacea schreb grass germinated and grew successfully, and the average height reached $25 \mathrm{~cm}$ after 90 days. However, the strength significantly decreased due to the porous concrete was immersed in $\mathrm{FeSO}_{4}$ solution, and meanwhile the effect of reducing alkali in porous concrete was not desirable. Furthermore, OPC was replaced by calcium aluminate cement (CAC), and adding fly ash into the $\mathrm{CAC}$ to reduce alkalinity in concrete, the results indicate Australian native grass species survive in vegetation concrete [18]. Although the effect of alkali reduction technique was obvious, the compressive strength of the porous concrete was only $1.19 \mathrm{MPa}$. Consequently, there are also some issues including the $\mathrm{pH}$ value, porosity, and the strength of vegetation concrete that need to be further examined.

In this work, a total of 10 groups mix proportion specimens of porous concrete were designed and constructed. As a result, the impacts of different parameters include the fly ash and silica fume content on the mechanical properties and porosity as well as the $\mathrm{pH}$ value of porous concrete were discussed. Meanwhile, eco-modified soil with resistance to the erosion of rainwater was sprayed on the surface of porous concrete for the survival of native grass growth. 
Table 1. The chemical composition of cement (\%).

\begin{tabular}{|c|c|c|c|c|c|c|c|c|}
\hline Composition & $\mathrm{Si}_{2} \mathrm{O}_{3}$ & $\mathrm{Al}_{2} \mathrm{O}_{3}$ & $\mathrm{CaO}$ & $\mathrm{Fe}_{2} \mathrm{O}_{3}$ & $\mathrm{SO}_{3}$ & $\mathrm{MgO}$ & $\mathrm{K}_{2} \mathrm{O}$ & $\mathrm{Na}_{2} \mathrm{O}$ \\
\hline P.O 42.5 Grade & 21.82 & 7.23 & 54.45 & 4.72 & 2.72 & 1.83 & 0.72 & 0.45 \\
\hline
\end{tabular}

Table 2. The physical properties of OPC.

\begin{tabular}{|c|c|c|c|c|c|c|c|c|}
\hline \multirow{2}{*}{$\begin{array}{c}\text { Type } \\
\text { of Cement }\end{array}$} & \multirow{2}{*}{$\begin{array}{c}\text { Fineness } \\
(\%)\end{array}$} & \multirow{2}{*}{$\begin{array}{c}\text { Standard } \\
\text { consistency } \\
(\%)\end{array}$} & \multicolumn{2}{|c|}{ Setting time (min) } & \multicolumn{2}{|c|}{ Flexural strength (MPa) } & \multicolumn{2}{c|}{$\begin{array}{c}\text { Compressive } \\
\text { strength (MPa) }\end{array}$} \\
\cline { 4 - 11 } & & & Initial setting & Final setting & $3 \mathrm{~d}$ & $28 \mathrm{~d}$ & $3 \mathrm{~d}$ & $28 \mathrm{~d}$ \\
\hline P.O 42.5 grade & 1.5 & 25.6 & $1 \mathrm{~h} 46 \mathrm{~min}$ & $2 \mathrm{~h} \mathrm{31 \textrm {min }}$ & 5.0 & 8.7 & 28.9 & 54.6 \\
\hline
\end{tabular}

In addition, the growth characteristics of the Festuca arundinacea schreb (Chinese grass) within eco-modified soil on the surface of porous concrete were observed and monitored for 8 weeks including the average height, root system development and relative coverage of grass.

\section{Experimental Program}

\section{Test Materials}

The materials used for the experiment can be divided into two major components, porous concrete and eco-modified soil. In this case, the porous concrete is performed for steep slope protection in practical engineering, and meanwhile the eco-modified soil is utilized to provide favorable survival environment for vegetation. The porous concrete was a composite material composed of cement, aggregate and mineral additives, and these materials were mixed to obtain desirable concrete performance. In this experiment, Ordinary Portland Cement (OPC) with 42.5 of grade was conducted as the primary binding material, and the chemical composition and physical properties of OPC are summarized in Table 1 and 2 respectively. Moreover, the mineral admixtures consist of fly ash and silica fume, which were used as a supplementary cementing material to reduce the cement amount, the chemical components of admixtures are listed in Table 3. In this case, fly ash of grade II with fineness less than $20 \%$, and the purity of silica fume exceeds $94 \%$ as well as the specific surface area is approximately $15000 \mathrm{~m}^{2} / \mathrm{kg}$. Meanwhile, 10 19 mm crushed gravel was adopted as coarse aggregate, the bulk density and apparent density of the aggregate were $1461 \mathrm{~kg} / \mathrm{m}^{3}$ and $2688 \mathrm{~kg} / \mathrm{m}^{3}$ respectively. In this test, no fines (sand) were used in the production of porous concrete to ensure the desired porosity. Besides, the superplasticizer with $30 \%$ of water-reducing rate, brown liquid, was used as other admixture.

As noted previously, to enhance the survival of grasses in vegetation concrete, the eco-modified soil was sprayed on surface of porous concrete slopes to provide the desirable growth condition of grasses. The ecomodified soil was mixed cement, greening additives, soil, humic substances and selected grass seeds in a specific proportion. In this work, the technique of the eco-modified soil is to employ special greening additives and to incorporate cement into the mulching material, and the intension of technique is to provide favorable and fast results in soil and water conservation and slope revegetation [2]. Moreover, the solidification effect of cement enhances the strength of eco-modified soil in a short time, enabling faster development of resistance to soil erosion. However, the $\mathrm{pH}$ value of ecomodified soil is relatively higher due to the existence of OPC. Therefore, in the experiment, the alkali reduction

Table 3. The chemical components of admixtures.

\begin{tabular}{|c|c|c|c|c|c|c|}
\hline Admixtures & $\mathrm{SiO}_{2}$ & $\mathrm{Al}_{2} \mathrm{O}_{3}$ & $\mathrm{CaO}$ & $\mathrm{Fe}_{2} \mathrm{O}_{3}$ & $\mathrm{MgO}$ & $\mathrm{SO}_{3}$ \\
\hline Fly ash & 42.5 & 24.7 & 3.9 & 20.5 & 1.2 & 0.83 \\
\hline Silicon fume & 92.1 & 1.6 & 0.6 & 0.7 & 0.9 & 0.5 \\
\hline
\end{tabular}

Table 4. Basic properties of chosen grass.

\begin{tabular}{|c|c|c|c|c|c|c|}
\hline Species & $\begin{array}{c}\text { Life } \\
\text { expectancy }\end{array}$ & $\begin{array}{c}\text { Average mature height } \\
(\mathrm{cm})\end{array}$ & Season & $\mathrm{pH}$ tolerance & Preferred soil type & Other tolerances \\
\hline $\begin{array}{c}\text { Festuca } \\
\text { arundinacea }\end{array}$ & Perennial & $90-120$ & Warm & $\begin{array}{c}\text { Mildly } \\
\text { acidic-Alkaline }\end{array}$ & $\begin{array}{c}\text { Sandy } \\
\text { to clay-loams }\end{array}$ & $\begin{array}{c}\text { High heat, High } \\
\text { drought }\end{array}$ \\
\hline
\end{tabular}


technology was also applied to eco-modified soil to provide lower $\mathrm{pH}$ or favorable survival environment. For this purpose, these materials including sulfur, gypsum, soil with yeast and lactic acid bacteria were mixed to decrease the alkalinity in the growth environment of vegetation. Some Chinese native grass species namely Ryegrass, Bermuda grass, Festuca arundinacea schreb, and Robinia pseudoacacia grows greatly flourishing in alkaline-resistant environment. Accordingly, to effectively observe the growth characteristics of grass, in this test, the Festuca arundinacea schreb seeds were mixed with eco-modified soil to spray on the surface of porous concrete. The basic performances of selected grass are given in Table 4. In addition, the details amount of these materials for the mix design of porous concrete are described in Table 5.

\section{Preparation Procedure and Test Specimens}

It is totally different from ordinary concrete on structure and damage characteristics for porous concrete, and the porosity is the main factor to the mix proportion design. Furthermore, the porous concrete has some specified requirements on aggregate gradation, cement content and the ratio of water/ binder, which need matches well with the demands of porosity and the corresponding strength. As mentioned above, porous concrete has a large amount of pores to ensure the grass growth, and the roots penetrate through pores in porous concrete into undisturbed soil strata. Sufficient strength can enhance the stability of structures for slope protection. However, there is still contradictory relationship between strength and porosity, the larger the porosity, the lower the strength. Therefore, these factors need to be taken into account in the mix proportion design of porous concrete.

\section{Mix Proportions}

A total of 10 group porous concrete specimens with different parameters, including fly ash and silica fume contents were designed and fabricated to obtain the optimal mix proportion, and they were labeled as CSF0-0 to CSF-3-2, respectively. In this experiment, the mineral admixtures on the fly ash and the silica fume were respectively mixed into the cement paste to replace the OPC. In this case, CSF-0-0 specimen was only kept cement as cementing material, CSF-1-0 CSF-1-2 were specimens with $5 \%$ of silica fume and different fly ash content, and the amount of fly ash added were $0 \%, 10 \%$ and 20\% respectively. Similarly, CSF-2-0 CSF-2-2 were specimens with $7.5 \%$ of silica fume and different fly ash content, and the amount of fly ash added were $0 \%, 10 \%$ and $20 \%$ respectively. Meanwhile, CSF-3-0 CSF-3-2 were specimens with $10 \%$ of silica fume and different fly ash content, and the amount of fly ash added were $0 \%, 10 \%$ and $20 \%$ respectively. Furthermore, for each specimen, the superplasticizer with $30 \%$ of waterreducing rate of $0.5 \%$ cement content (mass fraction), brown liquid, used as the admixture. The ratio of water/ binder and porosity of porous concrete were 0.32 and $25 \%$ respectively determined by preliminary trials and previous studies $[12,14]$. Volume method [19] has always been a common method on experimental research of porous concrete, which was adopted to conduct the mix proportion design in this work. Based on Eqs. (1) $\sim(4)$, the mix proportion amount of all specimens was calculated, and the results are summarized in Table 5.

$$
W_{G}=\rho_{G c} \cdot \alpha
$$

...where, $W_{G}$ is the amount of aggregate per unit volume $\left(\mathrm{kg} / \mathrm{m}^{3}\right) ; \rho_{\mathrm{Gc}}$ is the bulk density of aggregate $\left(\mathrm{kg} / \mathrm{m}^{3}\right) ; \alpha$ is the reduction coefficient, and crushed gravel is suggested to the value of 0.98 .

Table 5. Mix proportion design of porous concrete.

\begin{tabular}{|c|c|c|c|c|c|c|c|c|c|}
\hline \multirow[b]{2}{*}{ Mix code } & \multirow{2}{*}{$\begin{array}{l}\text { The ratio of } \\
\text { cement/binder }\end{array}$} & \multirow{2}{*}{$\begin{array}{l}\text { Aggregate } \\
\text { size/mm }\end{array}$} & \multirow{2}{*}{$\begin{array}{c}\text { Goal } \\
\text { porosity } \\
(\%)\end{array}$} & \multicolumn{6}{|c|}{ Unit weight $\left(\mathrm{kg} / \mathrm{m}^{3}\right)$} \\
\hline & & & & $\begin{array}{c}\text { Coarse } \\
\text { aggregate }\end{array}$ & Cement & $\begin{array}{l}\text { Silica } \\
\text { fume }\end{array}$ & $\begin{array}{l}\text { Fly } \\
\text { ash }\end{array}$ & Water & $\begin{array}{l}\text { Water } \\
\text { reducer }\end{array}$ \\
\hline CSF-0-0 & 0.32 & \multirow{10}{*}{$10 \sim 19$} & 25 & 1432 & 323.8 & 0.0 & 0.0 & 103.6 & 1.62 \\
\hline CSF-1-0 & 0.32 & & 25 & 1432 & 307.6 & 16.2 & 0.0 & 103.6 & 1.62 \\
\hline CSF-1-1 & 0.32 & & 25 & 1432 & 275.2 & 16.2 & 32.4 & 103.6 & 1.62 \\
\hline CSF-1-2 & 0.32 & & 25 & 1432 & 242.8 & 16.2 & 64.8 & 103.6 & 1.62 \\
\hline CSF-2-0 & 0.32 & & 25 & 1432 & 299.5 & 24.3 & 0.0 & 103.6 & 1.62 \\
\hline CSF-2-1 & 0.32 & & 25 & 1432 & 267.1 & 24.3 & 32.4 & 103.6 & 1.62 \\
\hline CSF-2-2 & 0.32 & & 25 & 1432 & 234.7 & 24.3 & 64.8 & 103.6 & 1.62 \\
\hline CSF-3-0 & 0.32 & & 25 & 1432 & 291.4 & 32.4 & 0.0 & 103.6 & 1.62 \\
\hline CSF-3-1 & 0.32 & & 25 & 1432 & 259.0 & 32.4 & 32.4 & 103.6 & 1.62 \\
\hline CSF-3-2 & 0.32 & & 25 & 1432 & 226.6 & 32.4 & 64.8 & 103.6 & 1.62 \\
\hline
\end{tabular}


a)

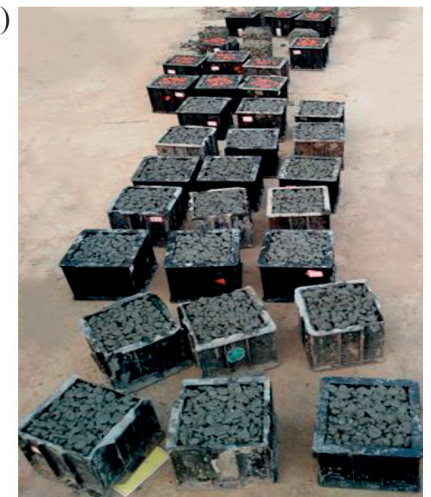

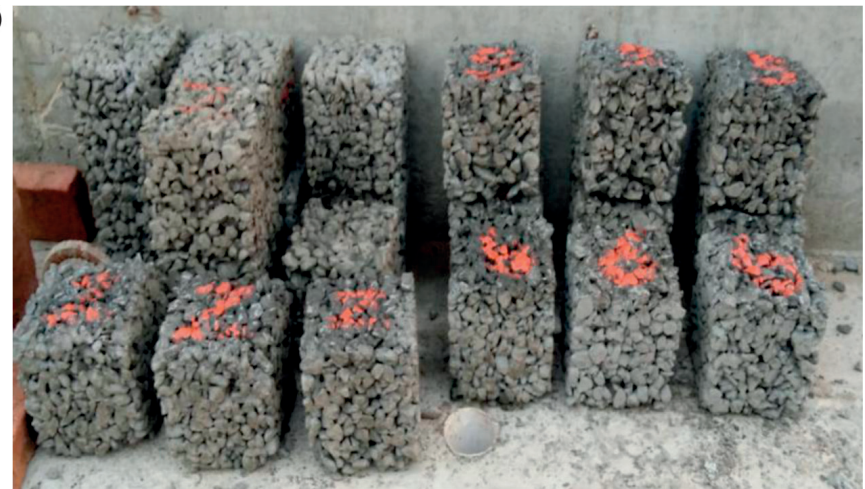

Fig. 1. Cubic blocks for testing. a) Cubic block with moulds. b) Cubic block with demoulded.

$$
W_{J}=\left(1-\frac{W_{G}}{\rho_{G}}-R_{\text {void }}\right) \times \rho_{J}
$$

...where $W_{J}$ is the cementitious material amount per unit volume $\left(\mathrm{kg} / \mathrm{m}^{3}\right) ; \rho_{G}$ is the apparent density of aggregate $\left(\mathrm{kg} / \mathrm{m}^{3}\right) ; R_{\text {void }}$ is the goal porosity of porous concrete; $\rho_{J}$ is the density of cementitious material $\left(\mathrm{kg} / \mathrm{m}^{3}\right)$.

$$
\begin{gathered}
W_{C}=\frac{W_{J}}{1+w / c} \\
W_{w}=W_{J} \times(w / c)
\end{gathered}
$$

...where $W_{c}$ is the amount of binder per unit volume $\left(\mathrm{kg} / \mathrm{m}^{3}\right) ; w / c$ is the ratio of water/binder; $W_{w}$ is the mixing water amount per unit volume $\left(\mathrm{kg} / \mathrm{m}^{3}\right)$;

Each batch of mixture was cast into standard cube moulds with dimension of $150 \mathrm{~mm} \times 150 \mathrm{~mm} \times 150 \mathrm{~mm}$ to measure the mechanical properties test (Fig. 1a). These samples were de-moulded after $24 \mathrm{~h}$ of curing, as shown in Fig. 1b), labelled and placed in the curing room (the temperature is $23 \pm 3^{\circ} \mathrm{C}$ and $59 \%$ relative humidity) until required for testing. Each group contains six identical cube test blocks to accurately obtain the physical and mechanical properties of porous concrete. Meanwhile, porous concrete with different mix proportion were also casted into 8 square brick moulds with dimensions of $500 \mathrm{~mm} \times 500 \mathrm{~mm} \times 100 \mathrm{~mm}$ for the observation of grass growth characteristics, and they were also labelled as CSF-0-0 to CSF-3-2 respectively (CSF-1-1 and CSF-2-1 were not included). These samples were cured for 24 hours at $23 \pm 3^{\circ} \mathrm{C}$ and $59 \%$ relative humidity, and the photograph of eight square brick moulds as shown in Fig. 2.

In addition, to further observe and monitor the grass growth characteristics in the vegetation concrete, the eco-modified soil was sprayed on the surface and filled into the pores to provide the adequate growth environment. In this case, the $3 \sim 4 \mathrm{~cm}$ thickness of eco-modified soil was sprayed on surface of the porous concrete, and which consists of cement, soil, humic substances, and greening additives and selected grass seeds. To promote the survival rate of grass seeds, the soil used in this work was sandy loam with $10 \%$ of sand, and the $\mathrm{pH}$ value around 6.4. Besides, to ensure effective room for growth and sufficient nutrition for grass, the humic substances included a mixture of fermented fungus packs and wood chips, which, when

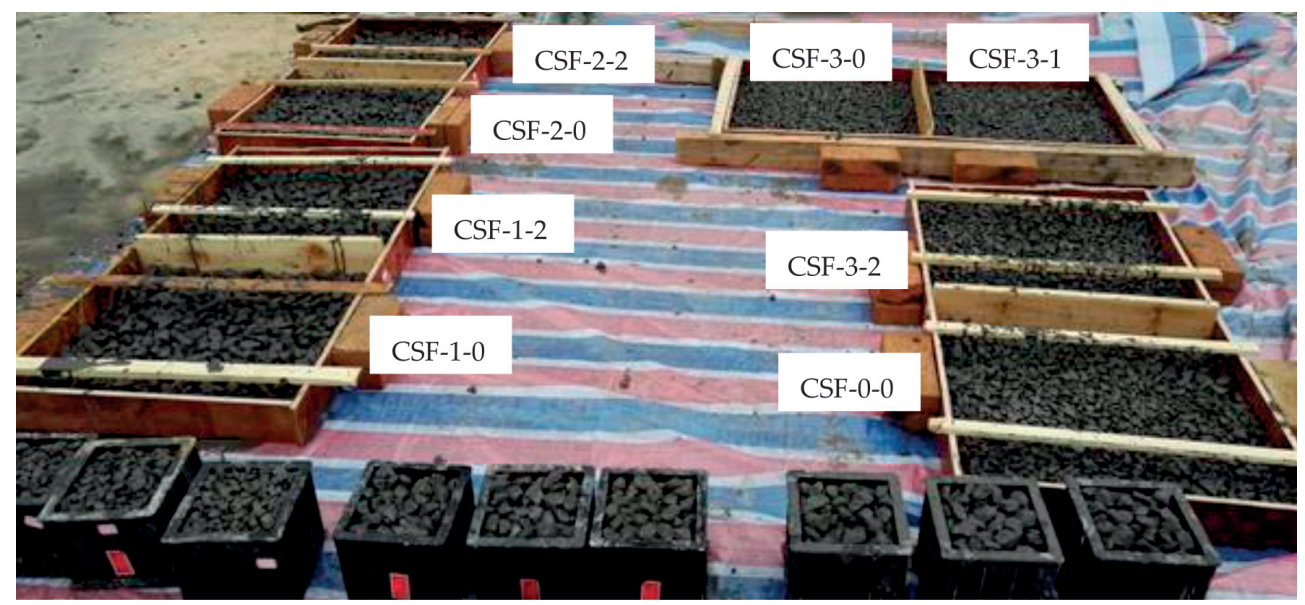

Fig. 2. The photograph of eight brick moulds. 
a)

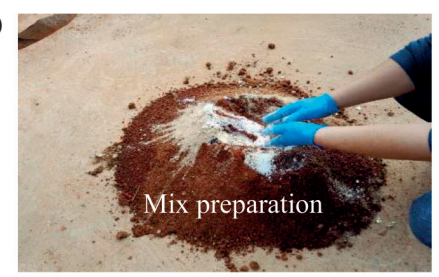

b)

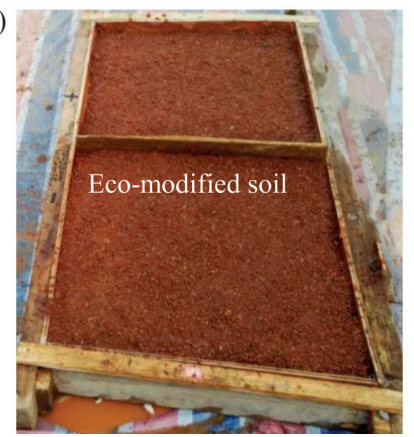

c)

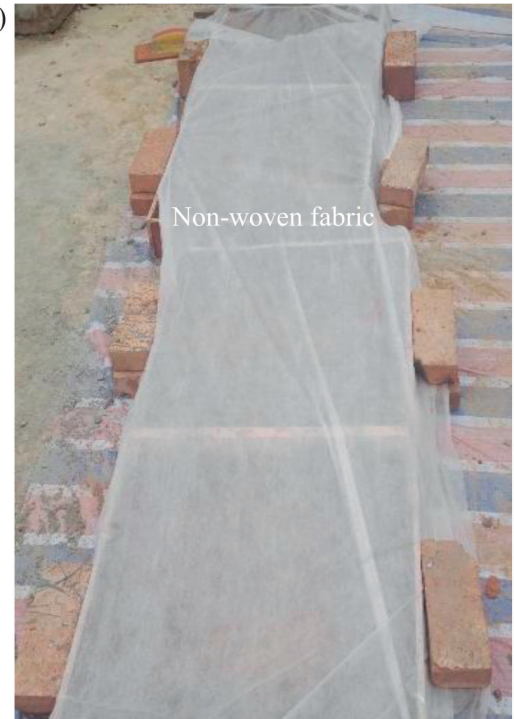

Fig. 3. The process of mixing and spray on eco-modified soil. a) Mix preparation. b) Mulch layer. c) Coverage maintenance with nonwoven fabric in glasshouse.

decomposed, became a source of nutrients and helped increase the porosity of eco-modified soil. The greening additives included slow-release fertilizers, waterretaining agents, and minerals. Slow-release fertilizers are compound fertilizers having long-term effects, such as urea, microbial fertilizers, and chemical compound fertilizers. For each $100 \mathrm{~g}$ of the sandy loam, the material included $8 \mathrm{~g}$ of cement, $5 \mathrm{~g}$ of greening additives, and $0.2 \mathrm{~m}^{3}$ of humic substances. Consequently, the surfacelayer material included $0.11 \mathrm{~m}^{3}$ of sandy loam, $10.3 \mathrm{~kg}$ of cement, $4.2 \mathrm{~kg}$ of greening additives, $5 \mathrm{~kg}$ of humic substances, and $320 \mathrm{~g}$ of selected grass seeds, as shown in Fig. 3a). It was observed that OPC causes the strongly alkaline environment in the process of hydration, and the environment not conducive to the growth of grass, which needs to be neutralized by adding neutralizer. Therefore, gypsum of $2 \%$ and sulfur of $0.6 \%$ sandy soil (mass fraction) were mixed into eco-modified soil performed in the experiment as the neutralizer to decline the alkalinity.

After the eco-modified soil was completely sprayed on the surface of square moulds of porous concrete, and each brick moulde was vibrated for approximately 30 s to ensure eco-modified soil could penetrate and a)
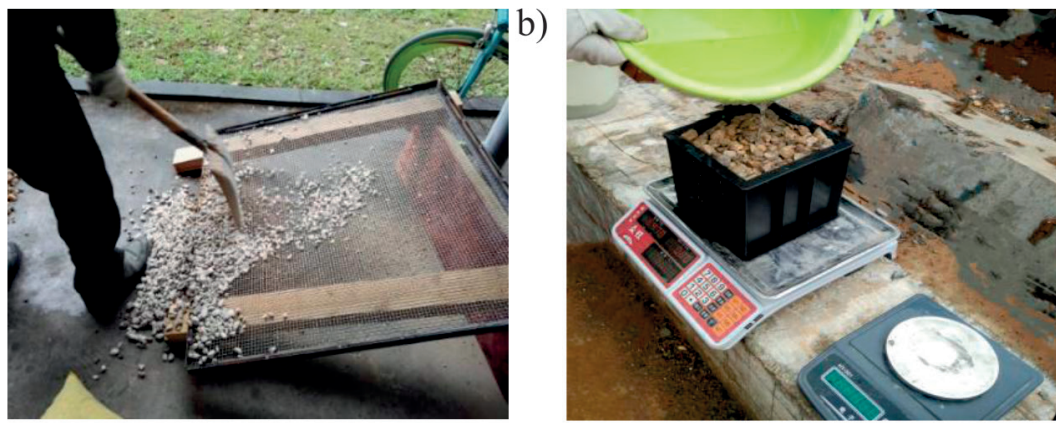

d)

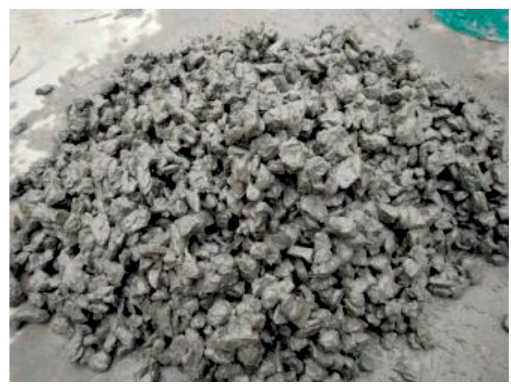

e)

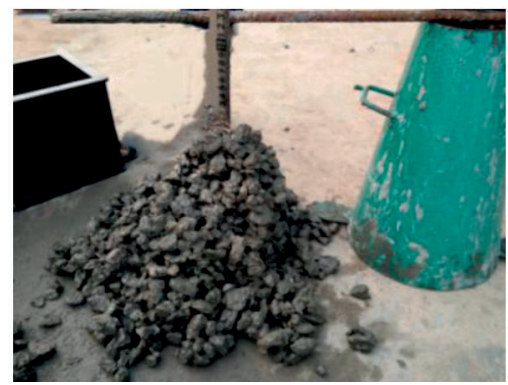

c)

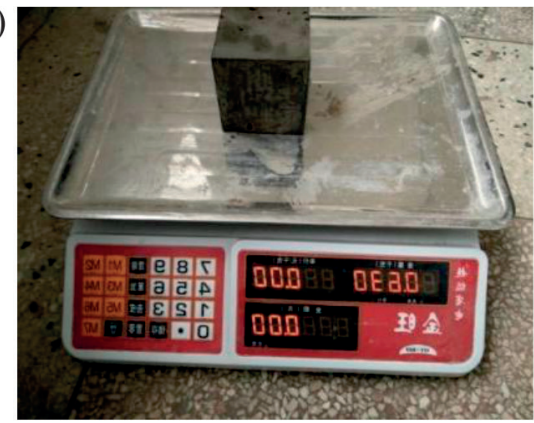

f)

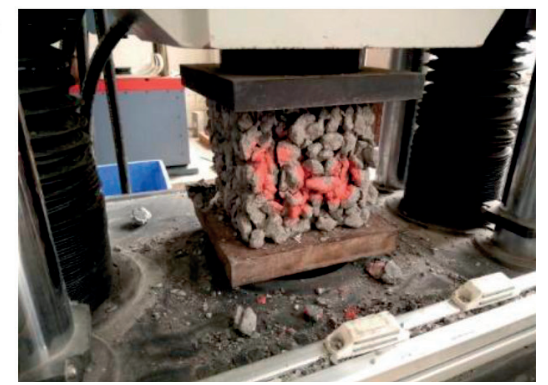

Fig. 4. Preparation and test process of porous concrete. a) Coarse aggregate screening. b) Accumulation density test of coarse aggregate. c) Density test of binder materials. d) Porous concrete. e) Slump test. f) Compressive strength test. 
Table 6. Summary of mechanical properties, porosity and alkalinity of the concretes.

\begin{tabular}{|c|c|c|c|c|c|c|c|c|}
\hline \multirow[t]{2}{*}{ Mix code } & \multirow[t]{2}{*}{$\begin{array}{l}\text { Coarse aggregate } \\
\text { size }(\mathrm{mm})\end{array}$} & \multicolumn{3}{|c|}{ Percentages of binder materials ( $\%$ ) } & \multirow{2}{*}{$\begin{array}{l}\text { Porosity at } \\
28 \text { days } p \\
\quad(\%)\end{array}$} & \multicolumn{2}{|c|}{$\begin{array}{l}\text { Compressive } \\
\text { strength at age } \\
(\mathrm{MPa})\end{array}$} & \multirow[t]{2}{*}{$\begin{array}{c}\text { Alkalinity at } 28 \\
\text { days (average } \mathrm{pH} \text { ) }\end{array}$} \\
\hline & & cement & silica fume & fly ash & & $7 \mathrm{~d}$ & $28 \mathrm{~d}$ & \\
\hline CSF-0-0 & \multirow{10}{*}{$10 \sim 19$} & 100 & 0 & 0 & 25.8 & 6.63 & 8.24 & 12.3 \\
\hline CSF-1-0 & & 95 & 5 & 0 & 23.6 & 6.92 & 9.18 & 11.5 \\
\hline CSF-1-1 & & 85 & 5 & 10 & 23.1 & 6.56 & 9.38 & 11.1 \\
\hline CSF-1-2 & & 75 & 5 & 20 & 22.6 & 6.41 & 9.57 & 10.7 \\
\hline CSF-2-0 & & 92.5 & 7.5 & 0 & 22.8 & 8.07 & 10.14 & 10.8 \\
\hline CSF-2-1 & & 82.5 & 7.5 & 10 & 22.6 & 7.42 & 10.85 & 10.5 \\
\hline CSF-2-2 & & 72.5 & 7.5 & 20 & 22.1 & 7.18 & 11.03 & 10.3 \\
\hline CSF-3-0 & & 90 & 10 & 0 & 22 & 9.48 & 11.58 & 10.1 \\
\hline CSF-3-1 & & 80 & 10 & 10 & 21.5 & 8.56 & 12.83 & 9.7 \\
\hline CSF-3-2 & & 70 & 10 & 20 & 21.0 & 8.02 & 13.22 & 9.4 \\
\hline
\end{tabular}

fill into the pores of porous concrete, as shown in Fig. 3b). Moreover, these porous concrete blocks were then covered with non-woven fabric to maintenance in glasshouse (Fig. 3c), and the average temperature in glasshouse was kept at the $26^{\circ} \mathrm{C}$ in day time and dropped to approximately $19^{\circ} \mathrm{C}$ at night, which maintains the temperature suitable for plant growth. As mentioned previously, the solidification effect of cement improves eco-modified soil strength in a short time, enabling faster development of resistance to soil erosion. For this purpose, 6 identical mixture samples of eco-modified soil were cast into cylinder moulds in a diameter of $40 \mathrm{~m}$ and height of $100 \mathrm{~mm}$ for each specimen, and the unconfined compression strength was measured respectively after 2 days and 14 days of curing based on the requirements of norm [20].

\section{Test Methods}

The compressive strength of porous concrete was measured after 7 days and 28 days of curing respectively, in accordance with the specification of GB/ T50081-2002 [21], as shown in Fig. 4. Meanwhile, the volumetric porosity of porous concrete was determined by the volume of water filled up the pores of cubic mould after prolonged immersion [1, 22]. Furthermore, the $\mathrm{pH}$ of hardened concrete was measured by extraction of pore solution after 28 days [23].

\section{Results and Discussion}

\section{Mechanical Properties of Porous Concrete}

The experimental results of the mechanical properties, porosity and alkalinity for each porous concrete specimen are summarized in Table 6. Fig. 5 depicts the compressive strength variations compared to the control mixture specimen (CSF-0-0). As seen in Fig. 5, the results indicate a trend of enhanced compressive strength (at $7^{\text {th }}$ and $28^{\text {th }}$ day of curing) significantly with increasing silica fume content, which matches well with the results of literature [11]. Accordingly, it was found that the impact of silica fume on the mechanical properties of porous concrete is significant, prompting the enhancement of compressive strength. Although silica fume doesn't hydrate reaction with water, and then it quickly undergoes secondary hydration under the excitation of $\mathrm{Ca}(\mathrm{OH})_{2}$ and some other compounds due to silicon fume has strong pozzolanic properties, generated crystalline structure of $\mathrm{C}-\mathrm{S}-\mathrm{H}$ with higher gelling strength finally. Additionally, the harmful holes in hardened cement paste were filled by secondary hydration products for the micro-particle characteristics of silica fume, and which improves the

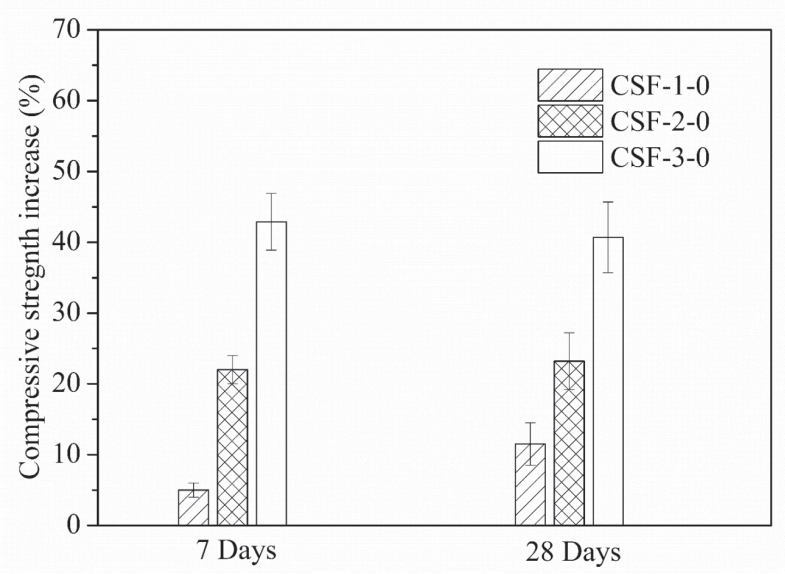

Fig. 5. Compressive strength variations compared to the control mixture (CSF-0-0). 
microstructure of hardened cement paste. As a result, it was observed that the compressive strength of porous concrete specimens after 7 days and 28 days of curing gradually increased as the increasing of silica fume content, the maximum strength increased by $42 \%$ compared with that of CSF-0-0 specimen (no silica fume).

Moreover, to further examine the influences of silica fume and fly ash contents on the mechanical properties of porous concrete, the compressive strength variations of specimens with different silica fume and fly ash contents are shown in Fig. 6a) and b respectively, where Fig. 6a) depicts the compressive strength variations under different silica fume content for specimens with fly ash of $10 \%$ and $20 \%$, and Fig. $6 \mathrm{~b}$ ) shows the compressive strength variations under different fly ash content for specimens with silica fume of $5 \%, 7.5 \%$ and $10 \%$. As can be seen in Fig. 6a), the compressive strength of concretes after 7 days and 28 days curing were enhanced significantly with the increasing silica fume content, the maximum strength increased by $47 \%$ and $43 \%$ respectively compared with that of CSF-1-1 and CSF-1-2 specimen (silica fume of 5\%).
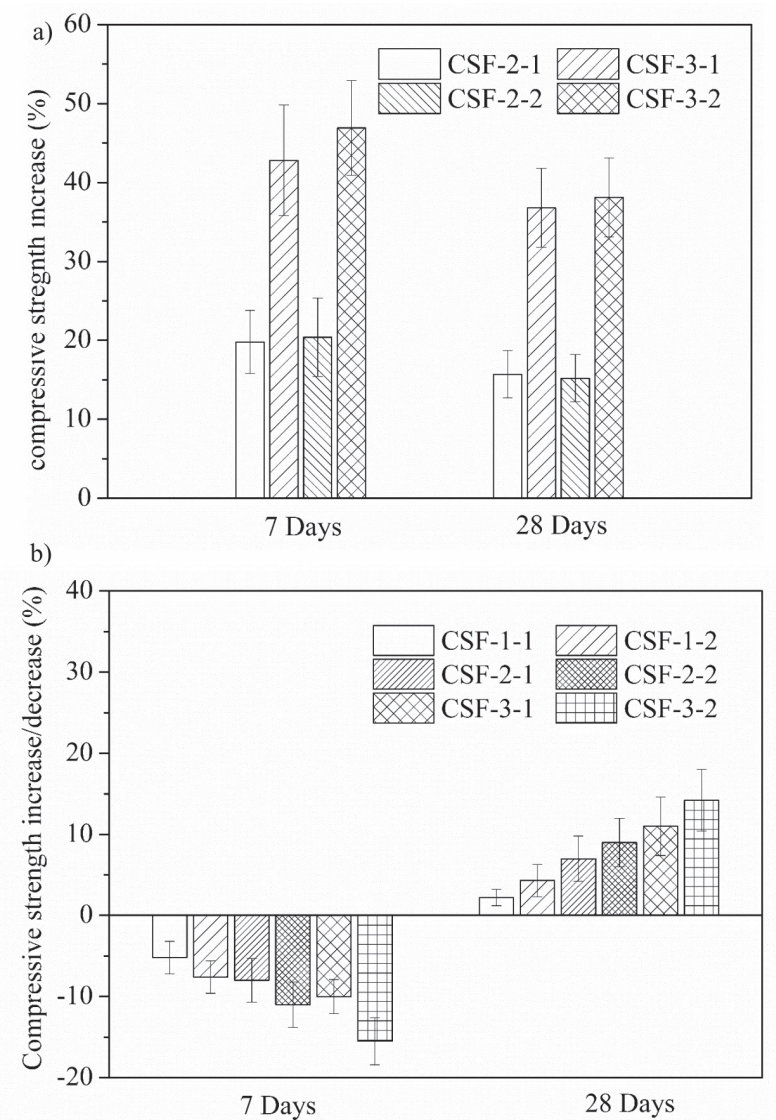

Fig. 6. The compressive strength variations for different silica fume and fly ash content. a) Compressive strength variations under different silica fume content for specimens with fly ash of $10 \%$ and $20 \%$. b) Compressive strength variations under different fly ash content for specimens with silica fume of $5 \%$, $7.5 \%$ and $10 \%$.
Meanwhile, it can be seen from Fig. 6b) that the compressive strength of 7 days decreased significantly as the increase of fly ash content, the compressive strength decreased by $15.5 \%$ compared with that of CSF-3-0 (no fly ash). However, the compressive strength at 28 days increased gradually with fly ash content continuing, and increased by $14.2 \%$. The reason of the above results is that $\mathrm{SiO}_{2}$ and $\mathrm{Al}_{2} \mathrm{O}_{3}$ in fly ash react to adequate $\mathrm{Ca}(\mathrm{OH})_{2}$ produced by cement hydration to generate calcium silicate and calcium aluminate hydrates, and these hydrates are filled into the pores to stimulate hardened cement more compacted. As a result, the interface structure of porous concrete improved remarkably and the strength enhanced tremendously because of the existence of $\mathrm{SiO}_{2}$ and $\mathrm{Al}_{2} \mathrm{O}_{3}$ in fly ash. In this regard, the hydration reaction of concrete is less significant at the early stage ( 3 or 7 days), and but the activity of fly ash needs to stimulate by a certain density of $\mathrm{Ca}(\mathrm{OH})_{2}$. Therefore, the compressive strength at 7 days declined obviously with the increase of fly ash. Whereas the hydration reaction of concrete is more obvious due to the high concentration of $\mathrm{Ca}$ $(\mathrm{OH})_{2}$ in the medium at 28 days, and thus the strength of concrete enhanced significantly as the continuing fly ash content.

Compared with the Fig. 6(a,b), it can be summarized that the effects of silica fume on strength are more obvious than those of fly ash. The compressive strength enhanced by silica fume much larger than that of fly ash at early stage (7 days), and even fly ash reduces the strength of concrete. Furthermore, both silica fume and fly ash mineral admixtures improve the strength of concrete at 28 days, and the strength of porous concrete mixed to silica fume is also significantly greater than that of fly ash.

\section{Physical Characterization of Porous Concrete}

Fig. $7 \mathrm{a}$ and $\mathrm{b}$ plots the porosity and average $\mathrm{pH}$ value of all porous concrete specimens after 28 days of curing respectively. As seen in Fig. 7a), the porosity at 28 days of porous concrete specimens was in the range of $21 \%-25.8 \%$. It was noteworthy that the porosity gradually decreased by increasing fly ash and silica fume content. Meanwhile, it was also found that the porosity of porous concrete reduced by silica fume is remarkably smaller than that of fly ash. The results are in accordance with the reference [24] in which the porosity was decreased for the microstructure of hardened cement paste in porous concrete improved by silica fume. As can be clearly seen from Fig. 7b) that the $\mathrm{pH}$ value of each porous concrete specimen at 28 days was found between 9.4 and 12.3, which is lower than the $\mathrm{pH}$ value in pore solution of OPC (around 12.4-13.5). In addition, it was also observed that the alkalinity in pores of concrete reduced significantly with the increase of fly ash or silica fume content. Compared with the CSF-0-0 specimen (no silica fume and ash fly), the $\mathrm{pH}$ of porous concrete was dropped to 
9.4 by adding $20 \%$ of fly ash and $10 \%$ of silica fume. It prepares a suitable environment for growing plants.

Based on the above results, the mix proportion of CSF-0-0 specimen was desirable in terms of pore availability, and which was determined by the highest porosity, as shown in Table 6. It was clearly observed that the porosity of porous concrete gradually decreased with the increase of silica fume and fly ash (Fig. 7a). However, it was also found that the compressive strength of CSF-0-0 was the smallest among other specimens. Compared with CSF-0-0 and CSF-3-2 specimen, it was noted that although the porosity of CSF-0-0 is larger than that of CSF-3-2, and but the difference between them was slight, less than of $18 \%$. Meanwhile, the strength of CSF-3-2 was above $60 \%$ greater than that of CSF-0-0. Besides, the lower $\mathrm{pH}$ value was measured in pores of CSF-3-2 specimen, as shown in Fig. 7b). Therefore, these indicators composed of the compressive strength, $\mathrm{pH}$ value and appropriate porosity need to be comprehensively considered into the mix proportion design of porous concrete and thus CSF-3-2 deemed to be optimal mix proportion for slope protection.

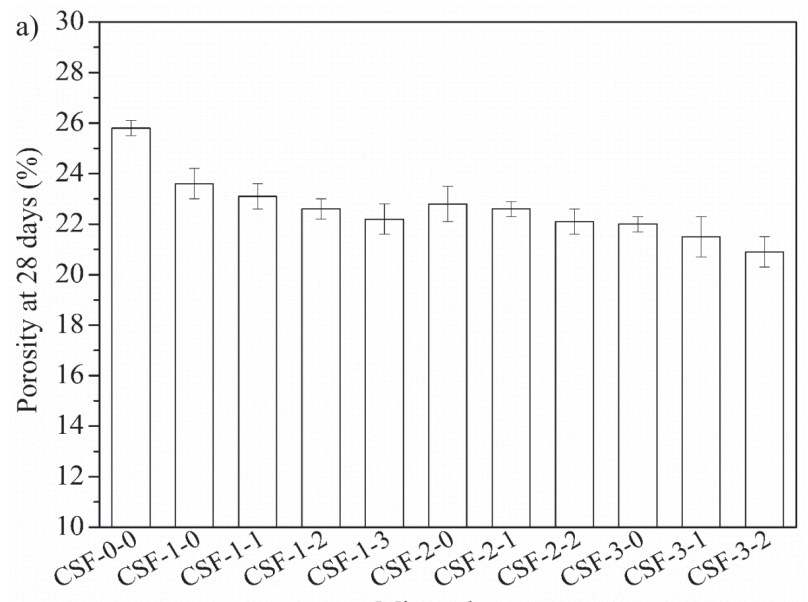

Mix code

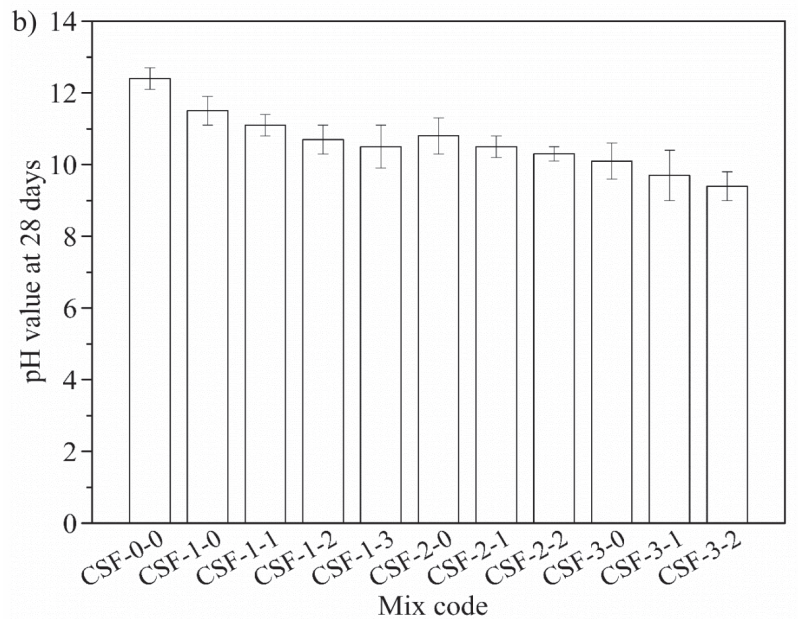

Fig. 7. The porosity and average $\mathrm{pH}$ value results of specimens. a) Measured porosity of each specimen. b) The average $\mathrm{pH}$ value of all concrete specimens.

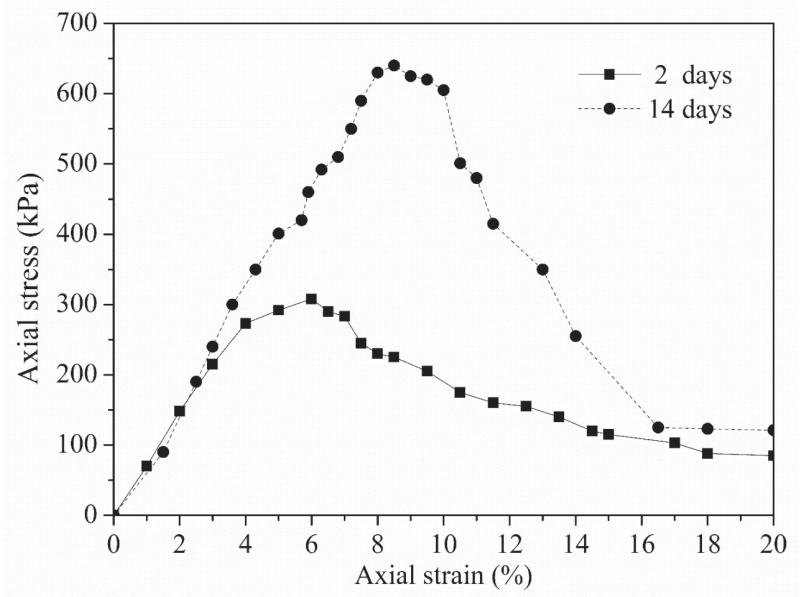

Fig. 8. The curves of unconfined compression strength for ecomodified soil after 2 days and 14 days of curing.

\section{Compressive Strength and $\mathrm{pH}$ Value of Eco-Modified Soil}

As noted previously, the strength of eco-modified soil enhanced by the solidification effect of cement in a short time, enabling faster development of resistance to soil erosion. Fig. 8 plots that the curves of unconfined compression strength for eco-modified soil after 2 days and 14 days of curing respectively. It can be seen from Fig. 8 that the axial stress of ecomodified soil after 2 days reached $308 \mathrm{kPa}$ when the axial strain was approximately 0.06 . Similarly, the maximum axial stress reached $640 \mathrm{kPa}$ for the ecomodified soil after 14 days when the corresponding axial strain was 0.085 . A study by Fan et al. [2] on shotcrete vegetation indicating the similar compressive strength with those results of this test, which was of around $0.59 \mathrm{MPa} \sim 0.67 \mathrm{MPa}$.

In addition, Fig. 9 plots that the curves of $\mathrm{pH}$ value in eco-modified soil with the increase of monitoring time. Meanwhile, to clearly observe the trend variations

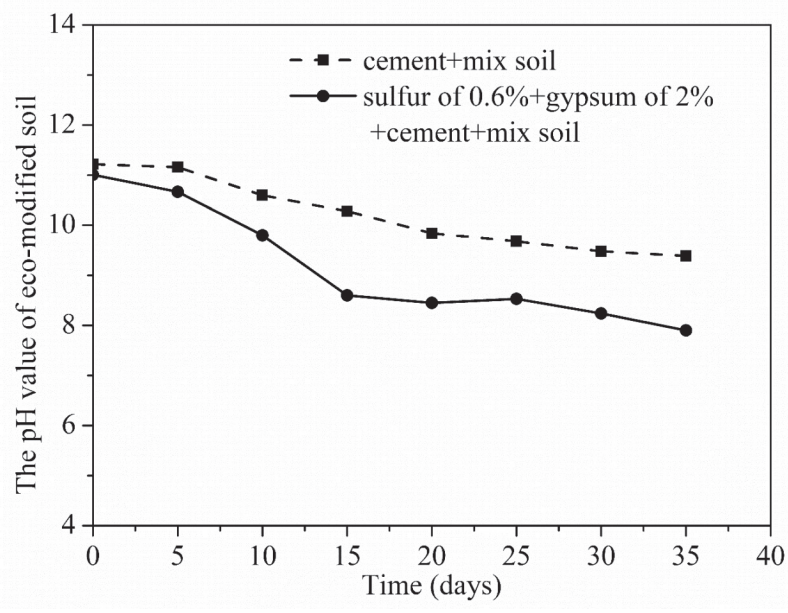

Fig. 9. The trend variations of $\mathrm{pH}$ value in eco-modified soil. 
a)

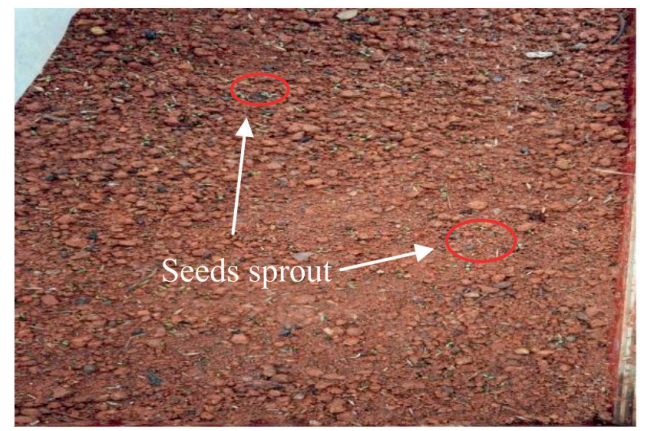

b)

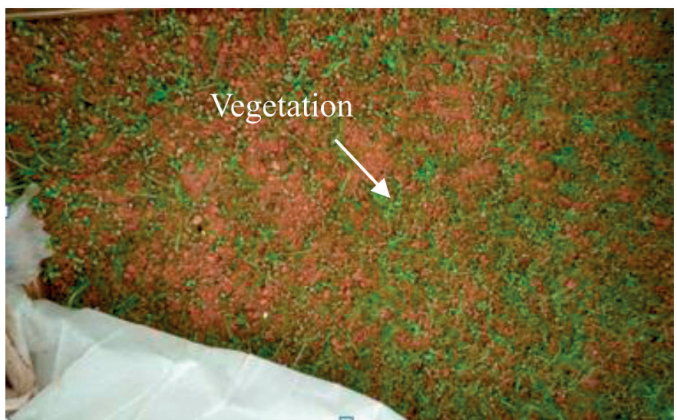

Fig. 10. The photographs of grasses germination in eco-modified soil. a) Three days after sowing. b) A week after sowing.

of $\mathrm{pH}$ value in eco-modified soil with $2 \%$ of gypsum and $0.6 \%$ of sulfur, the black dotted line in Fig. 9 shows the trend variations of $\mathrm{pH}$ value for only cement in ecomodified soil. As seen in Fig. 9, it was noteworthy that the $\mathrm{pH}$ value of eco-modified soil with $2 \%$ of gypsum and $0.6 \%$ of sulfur gradually decreased as the increase of monitoring time, and the $\mathrm{pH}$ value decreased remarkably after 20 days, decreased by $22 \%$. Besides, the $\mathrm{pH}$ value of eco-modified soil tended to flat after 30 days, the minimum $\mathrm{pH}$ value was 7.9. As a result, adding $2 \%$ of gypsum with appropriate nitrifying bacteria and $0.6 \%$ of sulfur into eco-modified soil can significantly reduce alkalinity of soil.

\section{Average Grass Heights and Coverage Observations}

\section{Grass Growth}

In this experiment, after all porous concrete specimen were cast and maintained, the eco-modified soil with seeds was sprayed on these eight specimens, and they were placed in the test room to monitor the germination and growth of vegetation, and coverage maintenance with non-woven fabric were conducted. For the temperature and relative humidity of the

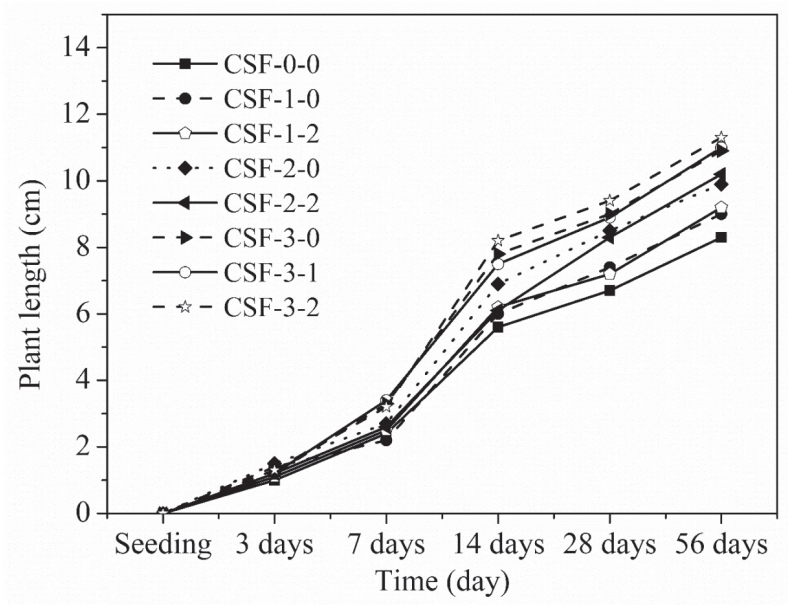

Fig. 11. Plants growth in laboratory for eight specimens. environment in test room, the daily highest temperature in the daytime is $31^{\circ} \mathrm{C}$, the lowest temperature in the evening is $19^{\circ} \mathrm{C}$, and the average relative humidity was $50.2 \%$. Three days or a week after sowing, seeds began to sprout and grow, as shown in Fig. 10.

a)

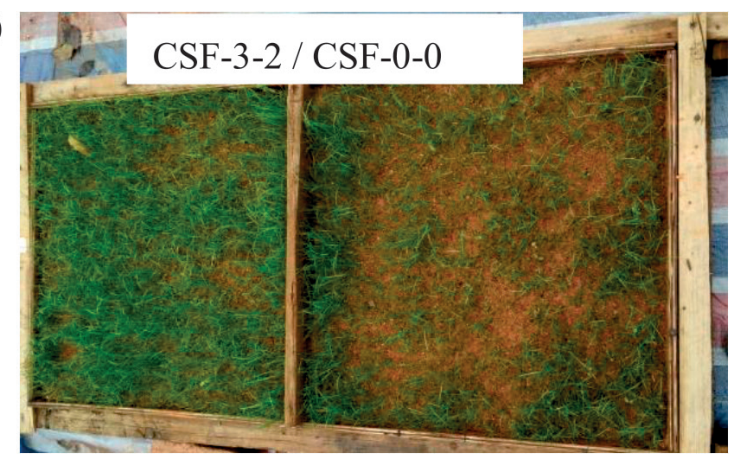

b)

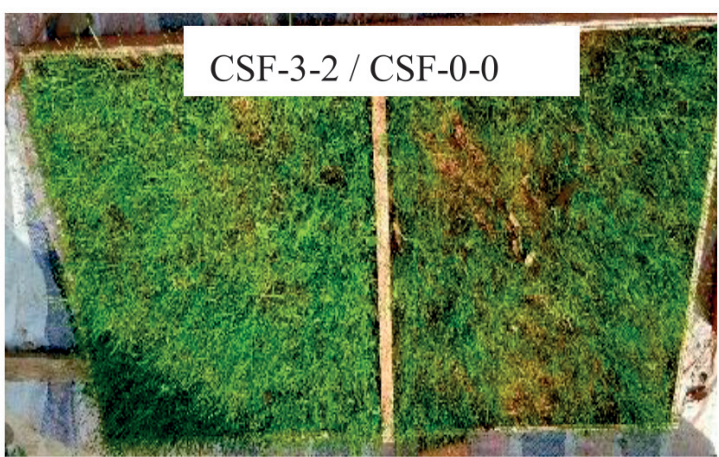

c)

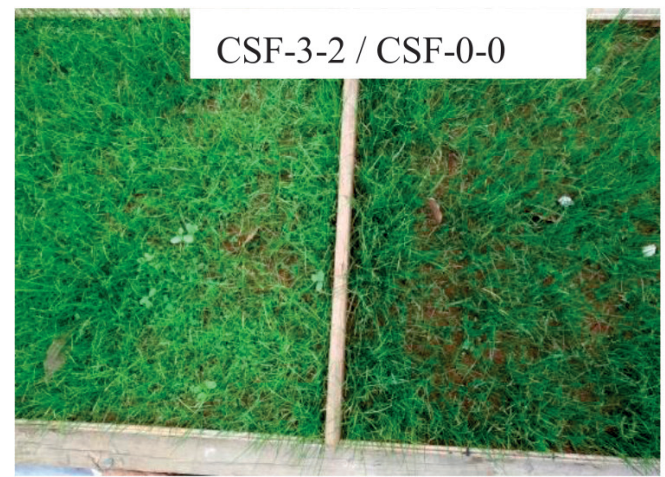

Fig. 12. The photographs on the growth of grass in CSF-3-2 and CSF-0-0 specimens. a) Two weeks. b) Four weeks. c) Eight weeks. 
In addition, Fig. 11 shows the growth length results of vegetation for each specimen with the increase of monitoring time. As seen in Fig. 11, it was observed that the length of the grass shoots was range of $10 \sim 15 \mathrm{~mm}$ after 3 days. The growth length of grass began to differ among each specimen at 7 days, and the length of grasses were between $22 \mathrm{~mm}$ and $34 \mathrm{~mm}$. After 14 days, the longest grass shoots (82 mm) was observed for the specimen with $10 \%$ of silica fume and $20 \%$ of fly ash (CSF-3-2), and while the grass length in CSF-0-0 specimen was only $56 \mathrm{~mm}$. After 28 days, the growth length of vegetation in CSF-3-2 specimen was $94 \mathrm{~mm}$, and the growth length in the control mixture (CSF-0-0) was $67 \mathrm{~mm}$. Moreover,
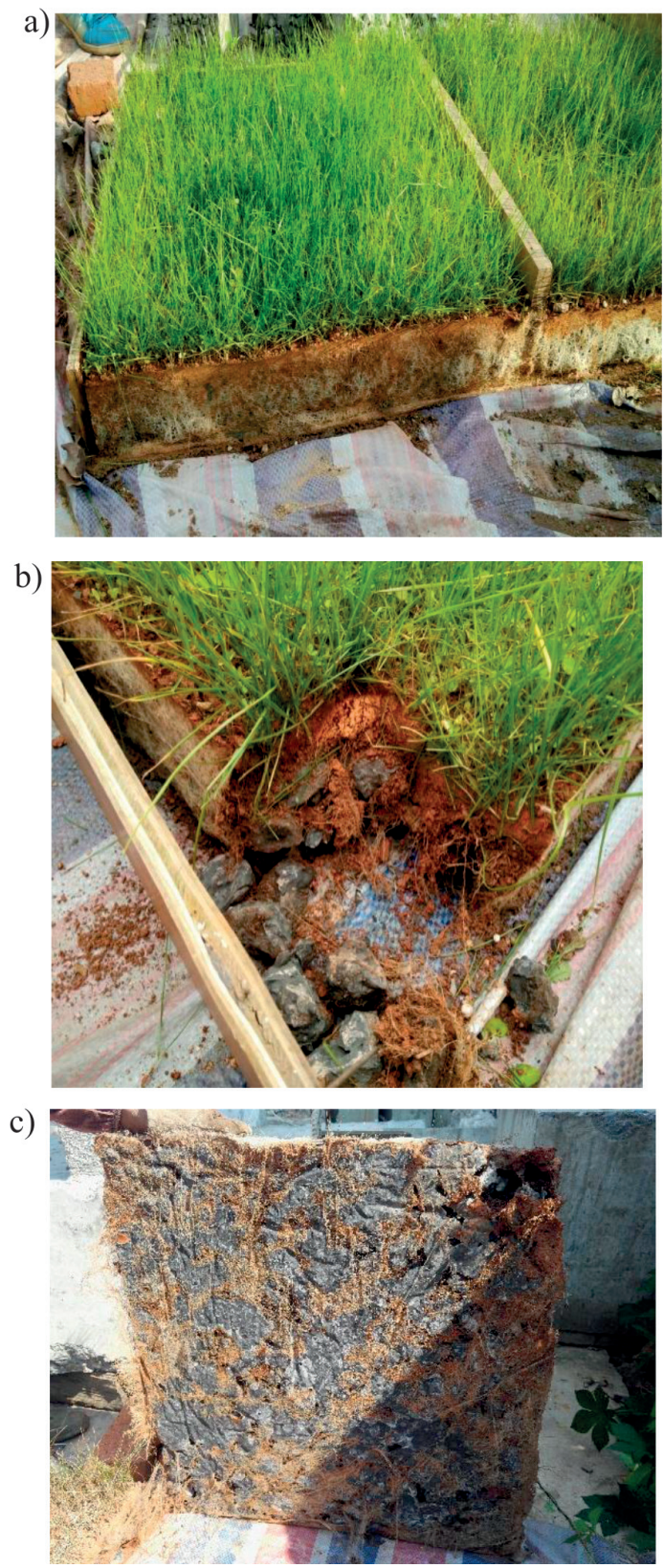

Fig. 13. Growth and development of grass roots for CSF-3-2 specimen. a) Vegetation growth and porous concrete. b) Growth of local root system. c) Root growth at the bottom of concrete. the CSF-3-2 specimen exhibited the longest grass shoot $(113 \mathrm{~mm})$ after 56 days whereas the growth length of grass in CSF-0-0 was only $83 \mathrm{~mm}$. Therefore, it can be summarized that the length of grasses increased significantly with the increasing silica fume content, and the length increased by $30 \mathrm{~mm}$ after 56 days compared with that of CSF-0-0 (no silica fume). Although the trend of grass growth length increased as the increase of fly ash content, and the length of grasses only increased by $2 \sim 4 \mathrm{~mm}$. As a result, the impact of silica fume on the growth length of vegetation is more significant than that of fly ash. Meanwhile, the photographs on the growth length of vegetation in CSF-3-2 and CSF-0-0 specimens respectively at various monitoring time are given in Fig. 12.

\section{Coverage and Vegetation Root System}

Based on the growth characteristics of grass in vegetation concrete specimens, after 28 days (four weeks), the coverage rate of vegetation reached $96 \%$ or above, as shown in Fig. 12b) and c). To further observe the growth characteristics of grass, the roots growth and development of vegetation in CSF-3-2 specimen after 56 days are given in Fig.13. The target performance was a compressive strength of $\geq 10 \mathrm{MPa}$, a porosity of $\geq 20 \%$, and $\mathrm{pH}$ value of $\leq 9.5$, and these properties were matched well with the vegetation concrete specimen (CSF-3-2) in this work, the photograph of porous concrete and vegetation growth was plotted in Fig. 13a). Meanwhile, it was also noticed that eco-modified soil has been filled into the porous concrete, and the root system of vegetation has embedded into the pores of porous concrete, as shown in Fig. 13b). As can be seen from Fig. 13c), the root development observations indicated that the integration of porous concrete and eco-modified soil was successful, and the technology provides environment-friendly protection for steep slope by planting native grass. The roots of vegetation have penetrated through the pores in porous concrete, and reached the bottom of the porous concrete.

\section{Conclusions}

In this work, the basic properties of porous concrete and the influences of silica fume and fly ash content on the strength, $\mathrm{pH}$ value and porosity of porous concrete were carried out. Meanwhile, the mix proportion and the alkali reduction technique of eco-modified soil have been obtained. In addition, the growth characteristics of the Festuca arundinacea schreb during eight weeks also have been observed and monitored. The results are summarized as follows.

1) The mechanical and physical characteristics of porous concrete indicate that the porous concrete is suitable for slope protection in practical engineering. The target performance was a compressive strength of $\geq 10 \mathrm{MPa}$, a porosity of $\geq 20 \%$, and $\mathrm{pH}$ value of $\leq 9.5$, 
and these properties were matched well with the porous concrete in this work. The compressive strength of porous concrete enhanced by the mineral admixtures of fly ash and silica fume.

2) The alkalinity and porosity in pores of concrete reduced significantly with the increase of fly ash or silica fume content, and the influences of silica fume on the strength, porosity and $\mathrm{pH}$ value are more significant than that of fly ash. The $\mathrm{pH}$ value of porous concrete was dropped to 9.4 by mixing $20 \%$ of fly ash and $10 \%$ of silica fume.

3) The $\mathrm{pH}$ value of eco-modified soil was significantly reduced by mixing the mixtures include $2 \%$ of gypsum with appropriate nitrifying bacteria and $0.6 \%$ of sulfur, and decreased to 7.9 .

4) In general, the integration of eco-modified soil and porous concrete was successful, all vegetation survived in the eco-modified soil and porous concrete environment for the duration of the observation period, and the coverage rate of vegetation reached $96 \%$ or above.

\section{Acknowledgements}

The authors gratefully acknowledge the financial supports provided by the National Natural Science Foundation of China (U1361204), the National Key Research Program of China (2016YFC0701700), and Hunan Provincial Innovation Foundation for Postgraduate (CX20190127, 2019zzts071).

\section{Conflicts of Interest}

The authors declare no conflict of interest.

\section{References}

1. LEKHA K.R. Field instrumentation and monitoring of soil erosion in coir-geotextile stabilized slopes-a case study. Geotext. Geomembr. 22, 399, 2004.

2. FAN J.C., HUANG C.L., YANG C.H., LIAO K.W., LIAO W.W. Effect evaluation of shotcrete vegetation mulching technique applied to steep concrete-face slopes on a highway of Taiwan. Paddy Water Environ. 11, 145, 2013.

3. LIU J., SHI B., JIANG H., HUANG H., WANG G., KAMAI T. Research on the stabilization treatment of clay slope topsoil by organic polymer soil stabilizer. Eng. Geol. 117, 114, 2011.

4. NI L., SULEIMAN M.T., RAICH A. Behavior and soil-structure interaction of pervious concrete groundimprovement piles under lateral loading. J. Geotech. Geoenviron. Eng. 142 (2), 04015071, 2015.

5. MORGAN R.P.C., RICKSON R.J. Slope Stabilization and Erosion Control: A Bioengineering Approach, 1st ed.; Routledge: London, UK, 1995.

6. ALAM M.A., HASELBACH L., COFER W. Validation of the Performance of Pervious Concrete in a Field Application with Finite Element Analysis. J. ASTM. International. 9 (4), 1, 2012
7. TSING C., SHEHATA M.H., LOTFY A. Optimizing a test method to evaluate resistance of pervious concrete to cycles of freezing and thawing in the presence of different deicing salts. Materials. 9 (11), 878, 2016.

8. KIM D.H., KIM C.S., PARK C.G. Physical and mechanical properties of non-cement porous concrete with alkaliactivator contents. J. KSAE. 52, 9, 2013

9. DUAN L., HUANG M., ZHUANG L. Differences in hydrological responses for different vegetation types on a steep slope on the Loess Plateau, China. J. Hydrol. 537, 356, 2016.

10. HU Y.Y., HU C.M., XIE L., GUO Q.W., WANG X. Effect of void status in eco-concrete for planting on plant growth. Journal of South China University of Technology, 34 (12), $5,2006$.

11. GAO J.M., JI B.H., WU C.D., LIU H.F. Experimental study on properties of green-growing porous concrete. Journal of Jiangsu University (Natural Science Edition). 26, 345, 2005.

12. XU F., XIAO D.Q. Research on mix proportion of nofines and porous concrete. Journal of Water Resources and Architectural Engineering. 4, 24, 2005.

13. LIU G. R., WAN W., LU C.H., WU C. D., PENG Z.H. Durability of cast-in situ eco-concrete used for ravageprotecting and plant-growing. Industrial Construction. 35, 668, 2005.

14. CHEN E., XU Y., WANG C., MAO J. Effects of concrete content on seed germination and seedling establishment in vegetation concrete matrix in slope restoration, Ecol. Eng. 58, 99, 2013.

15. SHI B., KONG X. Study on the vegetation restoration method to reinforce slope. In Proceedings of the $4^{\text {th }}$ GeoChina International Conference. Jinan, Shandong, 152, 2527 July, 2016.

16. BAO X., LIAO W., DONG Z., WANG S., TANG W. Development of vegetation-pervious concrete in grid beam system for soil slope protection. Materials. 10 (2), 96, 2017.

17. XU Y.L., LI R.W., TAN X.J., XIAO P., KUANG G.M. Planting experiment and preparation of porous concrete adapt to plants-growing, New Building Materials, 2, 16, 2009.

18. TANG W., MOHSENI E., WANG Z. Development of vegetation concrete technology for slope protection and greening. Constr. Build. Mater. 179, 605, 2018.

19. ZHANG Z.H. Study on porous vegetation-growing concrete. Master's Thesis, Chongqing university, Chongqing, China, 2006.

20. Ministry of water Resources of the People's Republic of China. Specification of soil test; SL237-1999; China Water Power Press: Beijing, China, 25 March 1999.

21. Chinese Academy of Architectural Sciences. Standard for test method of mechanical properties on ordinary concrete; GB/T 50081-2002; China Architecture \& Building Press, Beijing, China, 10 January 2003.

22. KIM H., PARK C. Plant Growth and Water Purification of Porous Vegetation Concrete Formed of Blast Furnace Slag, Natural Jute Fiber and Styrene Butadiene Latex. Sustainability. 8, 3864, 2016.

23. HUANG H.Q. The planting concrete test and its engineering application in slope of small river. Master's Thesis, Nanchang Institute of Technology, Nanchang, China, 2016.

24. LI Z.Q. Study on Properties of Porous Ecological Concrete for Plant-growing in China. Advanced Materials Research. 560, 600, 2012. 